\title{
Skull Base Clear Cell Carcinoma, Metastasis of Renal Primary Tumor: A Case Report and Literature Review
}

\author{
Ilson Sepúlveda ${ }^{\mathrm{a}, \mathrm{e}} \quad$ Enrique Platin $^{f}$ Rodrigo Klaassen ${ }^{\mathrm{b}}$ \\ M. Loreto Spencer ${ }^{b}$ Cesar García ${ }^{c}$ Ricardo Alarcón ${ }^{a}$ David Ulloa ${ }^{d}$ \\ ${ }^{a}$ ENT-Head and Neck Surgery Service, ${ }^{b}$ Pathology Service, and ${ }^{c}$ Oncology Service, General \\ Hospital of Concepcion, and ' San Sebastian University, School of Medicine, Concepcion, \\ and ${ }^{\mathrm{e}} \mathrm{Oral}$ and Maxillofacial Radiology, Finis Terrae University School of Dentistry, \\ Santiago, Chile; ${ }^{f}$ Division of Oral and Maxillofacial Radiology, University of North Carolina \\ School of Dentistry, Chapel Hill, N.C., USA
}

\section{Key Words}

Clear cell $\cdot$ Carcinoma $\cdot$ Tumor $\cdot$ CT $\cdot$ MRI $\cdot$ Metastases $\cdot$ Renal

\begin{abstract}
We report on a patient who presented with cranial nerve VI bilateral paresis, absence of pharyngeal reflex, dysarthria, right tongue deviation, and right facial paralysis. Imaging studies showed an expansive process in the cranial base with clivus and petrous apex osteolysis. A biopsy confirmed the presence of clear cell adenocarcinoma and suspicion of renal tumor metastases. Abdominal imaging studies revealed a mass in the right kidney. Consequently, radiotherapy was performed, and the patient was enrolled in a palliative care and pain control program.

(c) 2013 S. Karger AG, Basel
\end{abstract}

\section{Introduction}

Renal cell carcinoma (RCC) comprises $2-3 \%$ of all adult malignancies and $85 \%$ of malignant renal tumors. The highest incidence is found in individuals in the sixth and seventh decades of life, 66 being the median age at diagnosis [1-5]. RCC has a strong propensity to metastasize; $25 \%$ of patients initially present with distant metastasis and another $50 \%$ develop metastasis during follow-up $[1,6,7]$. It is the third most frequent neoplasm to metastasize to the head and neck region, preceded only by breast and lung cancer [1, 3-5, 810]. Although infrequently reported, head and neck regional metastases may be linked to 
RCC in up to $8-15 \%$ of cases $[1,2,4,6-9]$. The most affected regions of the head and neck include the paranasal sinuses, larynx, jaws, temporal bones, thyroid gland, and parotid glands. RCC metastases to the nose and paranasal sinuses are the most frequently affected areas, followed by the tongue $[1,3,9,11,12]$. The most common presenting symptoms to the head and neck region include an enlarging neck mass, epistaxis, anosmia, facial pain, nasal obstruction, and diplopia [6].

RCC is comprised of hypervascular tumors associated with multiple arteriovenous shunts due to the release of vascular endothelial growth factor as well as other angiogenic factors. Given the fact that the kidneys receive $25 \%$ of the circulating blood volume, RCC has a high spreading potential via the blood $[12,13]$.

RCC has 5 distinct histologic presentations: clear cell/conventional (75\%), papillary (15\%), chromophobe (5\%), collecting duct (2\%), and unclassified (3\%). Histopathologically, clear cell RCC typically shows a compact alveolar or solid architecture with varying degrees of cystic changes. RCC characteristically tends to exhibit numerous capillaries and thinwalled blood vessels in the supporting stroma. The cytoplasm is rich in lipids and glycogen; the latter 2 elements dissolve during processing to provide the characteristic clear cytoplasm $[2,7]$. Immunohistochemical staining helps in this distinction, exhibiting focal cytokeratin positivity (vs. minor salivary gland cancers that show diffuse positivity) and a strong reaction for vimentin [3].

Radiologic diagnosis is based on the vascular nature of the tumor, which shows moderate to marked signal enhancement on contrast CT. If contrast enhancement indicates destruction and lack of tumor calcification, metastatic RCC should be part of the differential diagnosis [5]. Radical nephrectomy is the standard of care for RCC. Palliative care for RCC metastasis is often the treatment of choice. Excision is usually performed to control pain and to manage any potential complications from space-occupying masses in the head and neck region, including the brain $[1,10]$. RCC does not respond well to radiation therapy, and while chemotherapy (interleukin-2, interferon- $\alpha$, and 5-fluorouracil) may be useful in cases of residual disease after resection, a positive response is experienced in less than $25 \%$ of patients [2]. Radiotherapy can only improve symptomatic relief and increase quality of life for perhaps a few months [1].

The 5-year survival rate for RCC after nephrectomy is 60-75\%. Excision of solitary metastatic lesions of RCC following nephrectomy results in a survival rate of $41 \%$ at 2 years and $13 \%$ at 5 years. The prognosis for patients with multiple RCC metastases is poor, with a 5-year survival rate of $0-7 \%[2,4,9,14]$.

\section{Case Report}

We report on a 62-year-old male who presented to the Ophthalmology Service with VI cranial nerve bilateral paresis, absence of pharyngeal reflex, dysarthria, right tongue deviation, and paralysis to the right side of the face. CT and MRI were performed, with CT showing a large expansive process at the cranial base with clivus and right petrous apex osteolysis (fig. 1). Poor enhancement was seen following intravenous contrast injection associated with rhinopharyngeal involvement (fig. 2).

An MRI T1 sequence showed a solid isointense expansive process with bilateral internal carotid artery involvement (fig. 3). An MRI T2 sequence revealed small hyperintense areas indicative of being cystic in nature or suggestive of central necrosis (fig. 4). Ipsilateral side secretions coming from the Eustachian tube indicated the mastoid region had been compromised. An additional MRI T1 sequence following administration of gadolinium 
contrast material showed moderate enhancement with clear involvement of bilateral internal carotid arteries (fig. 5) and the cavernous sinus, posterior ethmoidal sinus, clivus and both petrous apex infiltration. In addition, nasal and posterior superior rhinopharyngeal wall involvement was observed (fig. 6).

After imaging analysis, the patient was referred to the ENT service and a biopsy was performed. The diagnosis was clear cell adenocarcinoma and suspicion of renal tumor metastases. The Head and Neck Cancer Committee recommended ultrasonography, which subsequently revealed a heterogeneous echogenic multilobular mass on the right kidney, with irregular contours (fig. 7, fig. 8, fig. 9).

Pelvic and abdominal CT was performed, revealing a large mass on the right kidney with irregular contours and poor definition. Further investigations performed following contrast injection revealed a heterogeneous density with a hypodense central area and some calcifications in thickness (hyperdense deposits in the body of the primary tumor: right kidney) (fig. 10). Radiotherapy was recommended, but due to the advanced stage of the disease the patient was enrolled in a palliative care and pain control program.

\section{Conclusion}

Metastases of malignances in the head and neck are rare. When present, they tend to be very aggressive due to the advance stage of the disease. Multidisciplinary management, clinical experience and high-resolution imaging support are crucial for determining tumor identification, primary tumor localization, and the extent of tumor involvement.

\section{Disclosure Statement}

The authors have no conflicts of interest to declare.

\section{References}

1 Ogunyemi O, Rojas A, Hematpour K, Rogers D, Head C, Bennett C: Metastasis of genitourinary tumors to the head and neck region. Eur Arch Otorhinolaryngol 2010;267:273-279.

-2 Dashow JE, Gemmete JJ, McHugh JB, Helman JI: Metastatic clear cell renal carcinoma of the palate mimicking noninvoluting congenital hemangioma. J Oral Maxillofac Surg 2011;69:1836-1841.

-3 Will TA, Agarwal N, Petruzzelli GJ: Oral cavity metastasis of renal cell carcinoma: a case report. J Med Case Rep 2008;2:313.

4 Pompeo AC, Kanashiro H, Silva MN: Renal cell carcinoma presenting as a cervical mass. Int Braz J Urol 2005;31:151-152.

5 Yeh HC, Yang S-F, Ke HL, Lee KS, Huang CH, Wu WJ: Renal cell carcinoma presenting with skull metastasis: a case report and literature review. Kaohsiung J Med Sci 2007;23:475-479.

6 Schwab B, Lee WT: Bilateral renal cell carcinoma metastasis in the oral cavity. Am J Otolaryngol 2012;33:154-155.

-7 Serouya SM, Dultz LA, Concors SJ, Wang B, Patel KN: Late solitary metastasis of renal cell carcinoma to the submandibular gland. J Oral Maxillofac Surg 2012;70:2356-2359.

8 Duran Moreno DJ, Capitan LM, Labrot IL, Cabello A: Missed diagnosis of long-term head and neck metastasis of renal clear cell carcinoma. Two case reports. J Craniomaxillofac Surg 2006;34(suppl 1):60.

-9 Ishak AI, Pauzi SH, Masir N, Goh BS: Multiple metastatic deposits in the head and neck region from a renal cell carcinoma. Malays J Med Sci 2010;17:71-74.

10 Balliram S, Goetz L, Ramsoobhag K, Narinesingh D, Medford S, Naraynsingh V: Renal cell carcinoma presenting as a tongue lesion. J Oral Maxillofac Surg 2012;70:1605-1608.

11 Morvan JB, Veyrières JB, Mimouni O, Cathelinaud O, Allali L, Verdalle P: Clear-cell renal carcinoma metastasis to the base of the tongue and sphenoid sinus: two very rare atypical ENT locations. Eur Ann Otorhinolaryngol Head Neck Dis 2011;128:91-94. 


\section{Case Reports in Oncology}

\begin{tabular}{l|l}
\hline Case Rep Oncol 2013;6:416-423 & \\
\hline DOI: $10.1159 / 000354575$ & $\begin{array}{l}\text { C 2013 S. Karger AG, Basel } \\
\text { www.karger.com/cro }\end{array}$ \\
\hline
\end{tabular}

Sepúlveda et al:: Skull Base Clear Cell Carcinoma, Metastasis of Renal Primary Tumor: A Case Report and Literature Review

12 Spreafico R, Nicoletti G, Ferrario F, Scanziani R, Grasso M: Parotid metastasis from renal cell carcinoma: a case report and review of the literature. Acta Otorhinolaryngol Ital 2008;28:266-268.

13 Deeb R, Zhang Z, Ghanem T: Metastatic renal cell carcinoma to the parotid gland in the setting of chronic lymphocytic leukemia. Case Rep Med 2012;2012:265708.

14 Heffess CS, Wenig BM, Thompson LD: Metastatic renal cell carcinoma to the thyroid gland. A clinicopathologic study of 36 cases. Cancer 2002;95:1869-1878.

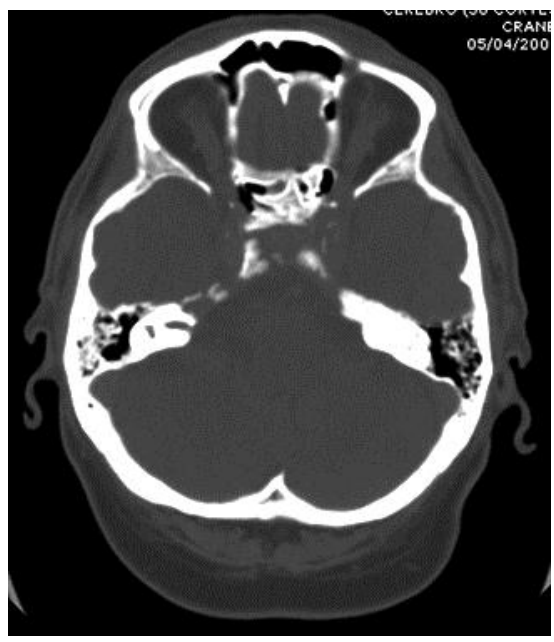

Fig. 1. Expansive process in the clivus and right petrous apex.

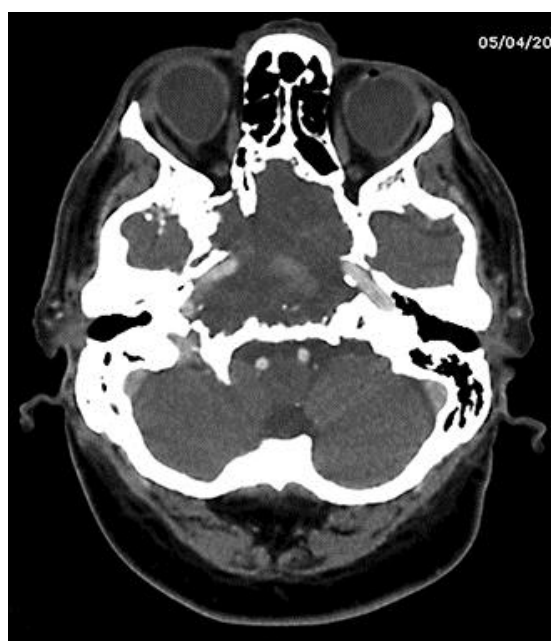

Fig. 2. Poor enhancement after intravenous contrast injection. 


\section{Case Reports in Oncology}

\begin{tabular}{l|l}
\hline Case Rep Oncol 2013;6:416-423 \\
\hline DOI: 10.1159/000354575 & $\begin{array}{l}\text { ○ } 2013 \text { S. Karger AG, Basel } \\
\text { www.karger.com/cro }\end{array}$ \\
\hline
\end{tabular}

Sepúlveda et al:: Skull Base Clear Cell Carcinoma, Metastasis of Renal Primary Tumor: A Case Report and Literature Review

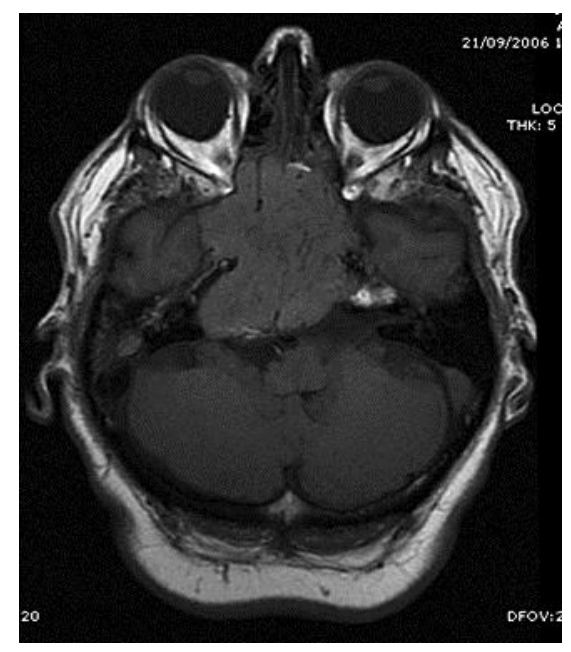

Fig. 3. MRI, T1 sequence. Isointense mass with bilateral internal carotid artery involvement.

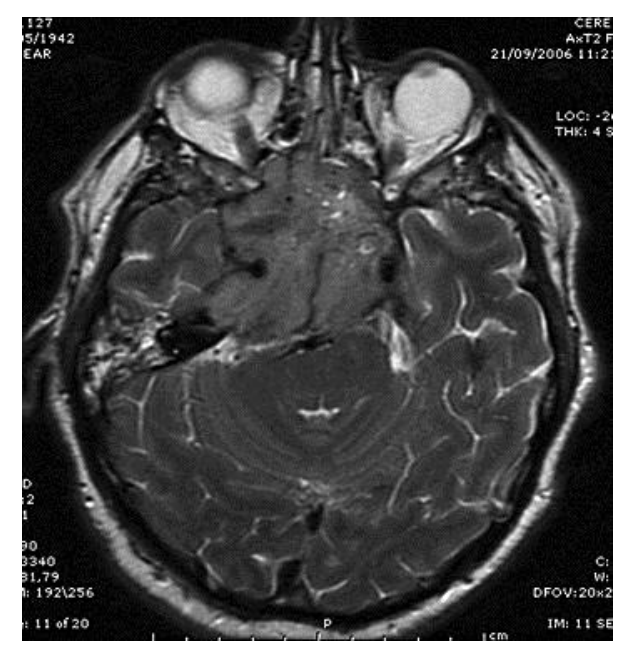

Fig. 4. MRI, T2 sequence. Hyperintense central areas suggest cyst degeneration or central necrosis. 


\section{Case Reports in Oncology}

\begin{tabular}{l|l}
\hline Case Rep Oncol 2013;6:416-423 \\
\hline DOI: $10.1159 / 000354575$ & $\begin{array}{l}\text { C 2013 S. Karger AG, Basel } \\
\text { www.karger.com/cro }\end{array}$ \\
\hline
\end{tabular}

Sepúlveda et al: Skull Base Clear Cell Carcinoma, Metastasis of Renal Primary Tumor: A Case Report and Literature Review

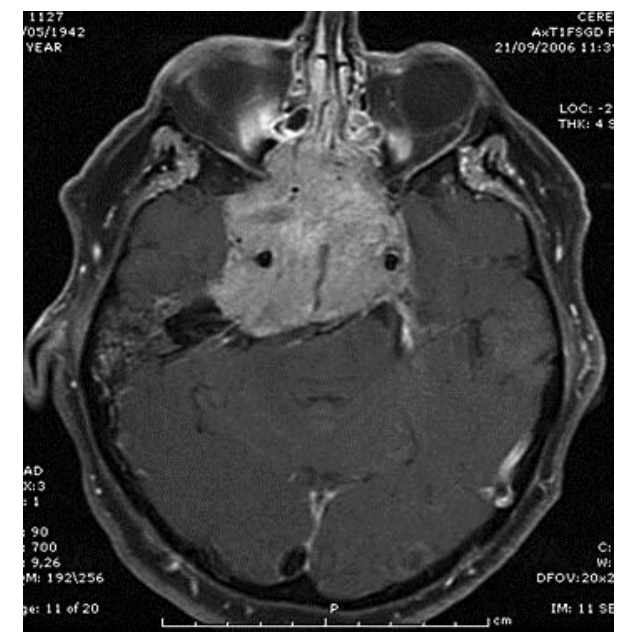

Fig. 5. MR T1 FSGD (fat saturation and gadolinium). Moderate enhancement and bilateral internal carotid artery involvement.

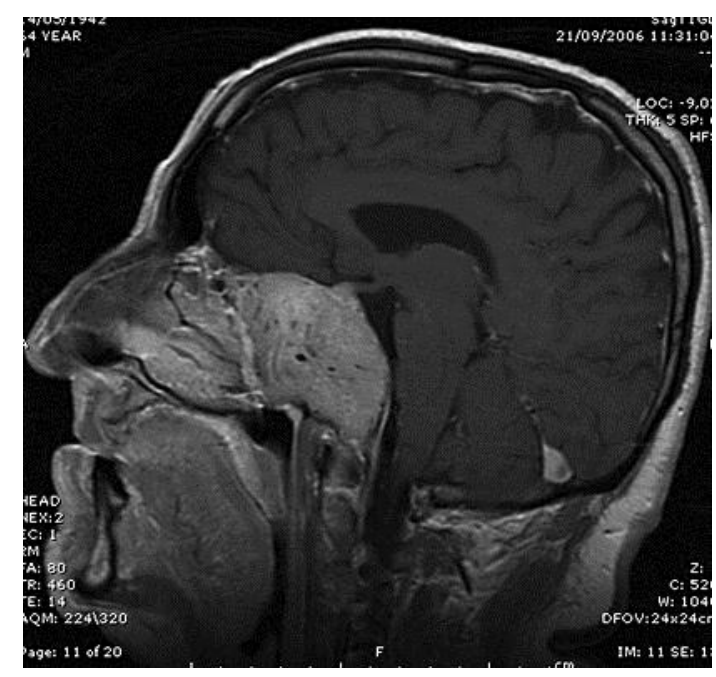

Fig. 6. MR T1 FSGD (fat saturation and gadolinium). Nasal and posterior nasopharyngeal wall involvement. 


\section{Case Reports in Oncology}

\section{DOI: $10.1159 / 000354575$}

Sepúlveda et al.: Skull Base Clear Cell Carcinoma, Metastasis of Renal Primary Tumor: A Case Report and Literature Review

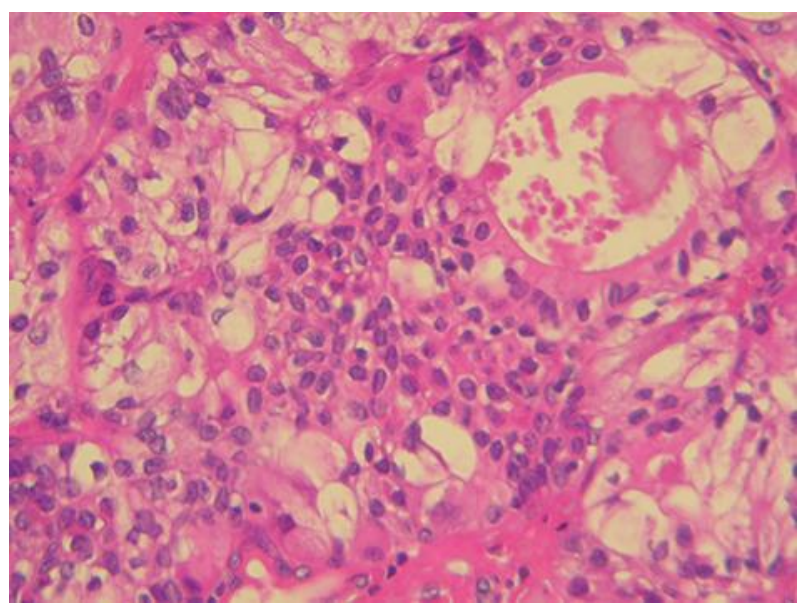

Fig. 7. HE. Clear cells with poor atypia.

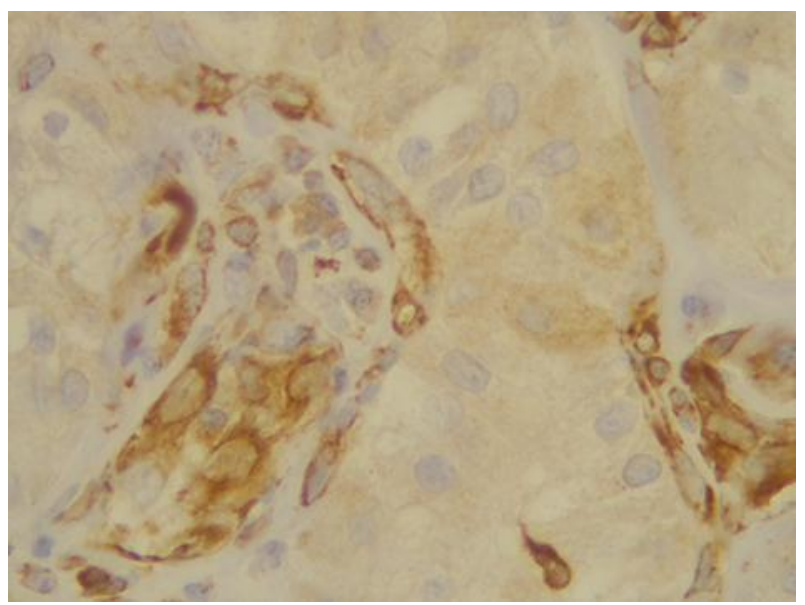

Fig. 8. Immunohistochemical stain: vimentin positive. 


\section{Case Reports in Oncology}

\begin{tabular}{l|l}
\hline Case Rep Oncol 2013;6:416-423 \\
\hline DOI: $10.1159 / 000354575$ & $\begin{array}{l}\text { (c) 2013 S. Karger AG, Basel } \\
\text { www.karger.com/cro }\end{array}$ \\
\hline
\end{tabular}

Sepúlveda et al.: Skull Base Clear Cell Carcinoma, Metastasis of Renal Primary Tumor A Case Report and Literature Review

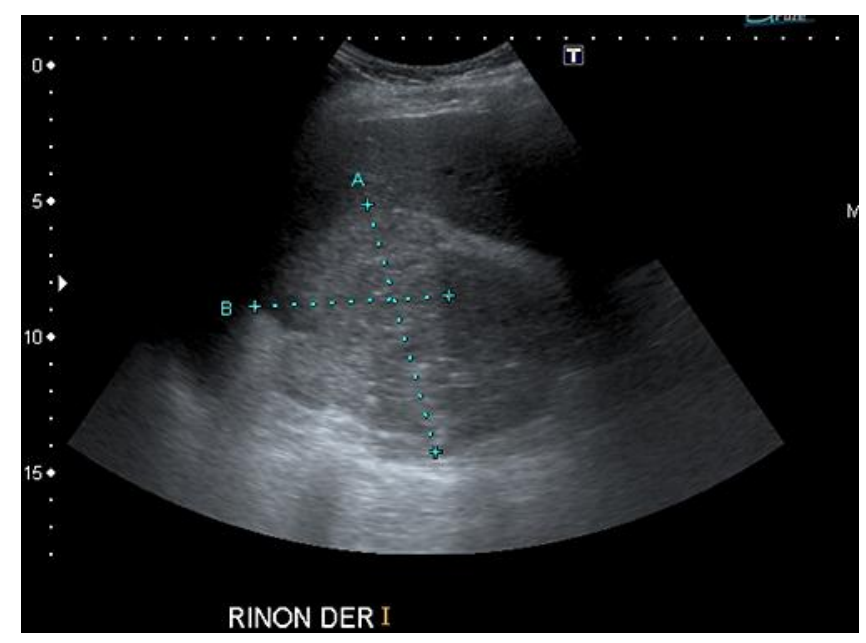

Fig. 9. Right kidney echo tomography: multilobular mass with heterogeneous echogenicity.

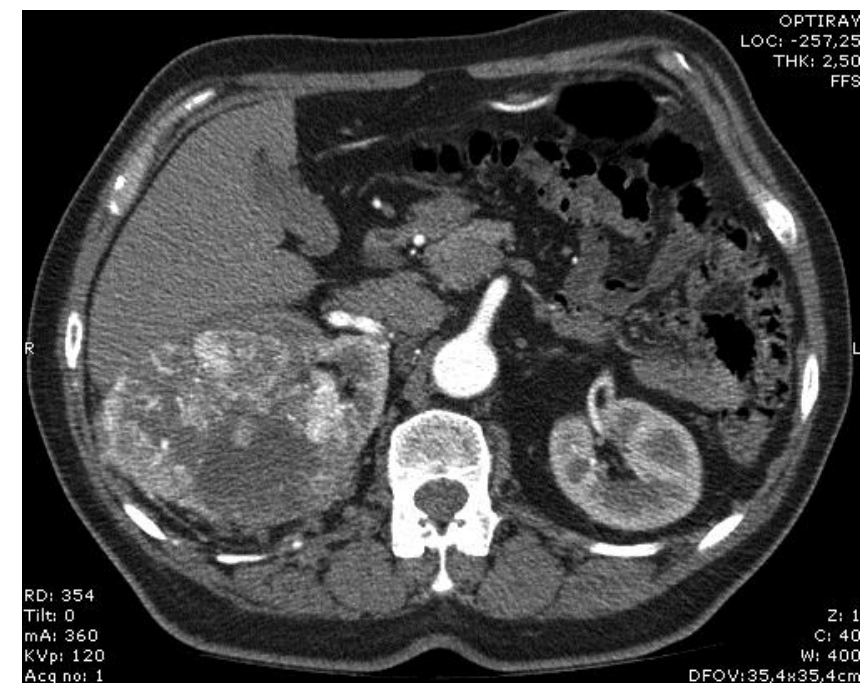

Fig. 10. Right kidney: expansive mass with irregular contours, heterogeneous enhancement and density; central necrotic areas. 